which the Association as well as the compilers are to be warmly congratulated. If it is widely and wisely read it could do a great deal to remove the weaknesses in education which have been the subject of present-day complaints, and it behoves the universities to make sure that no obsolete entrance requirements are allowed to frustrate the adoption in the schools of courses of the type herein proposed.

\section{Measurements of Standard Frequency Transmissions}

Measuremen's of the deviations of standard frequency transmissions have been made for a number of years by the Standards Division of the National Physical Laboratory, Teddington. Publication of these values, which related to Rugby transmitters, $M S F 60 \mathrm{kc} / \mathrm{s}$ and $G B R$ $16 \mathrm{kc} / \mathrm{s}$, and the Droitwich $200-\mathrm{kc} / \mathrm{s}$ transmitter of the British Broadcasting Corporation, were discontinued in July 1962 when the journal in which they had appeared ceased to exist. Arrangements have now been made between the Director of the National Physical Laboratory and the Council of the British Institution of Radio Engineers for these standard frequencies to be published each month in the Institution's journal, The Radio and Electronic Engineer. The first set of values relating to the month of June 1963 were published in the July 1963 issue. A short communication from the National Physical Laboratory explaining the methods of measurements appears in The Radio and Electronic Engineer for July.

\section{Studies in Density Difference Phenomena}

THE Department of Scientific and Industrial Research has granted $£ 38,000$ to Prof. W. Frazer and Dr. D. I. H. Barr, of the Civil Engineering Department of the Royal College of Science and Technology, Glasgow, in aid of integrated field and laboratory studies in density difference phenomena. The grant will allow for the extension of the present laboratory apparatus in which basic studies of the phenomena are carried out, and will enable the College to purchase and man a vessel with which intensive field studies can be initiated.

Density currents are set up in bodies of water when a flow differing in density from the receiving body is introduced. This can occur in many ways-by the fresh water from a river entering an estuary or the sea; by hot circulating water from the cooling system of a thermal power station being discharged into the sea or a river; and by the discharge of a sewage outfall. Mixing does not occur immediately and in many cases the introduced water can be traced for considerable distances. A striking example is the fact that the fresh-water flow from the River Amazon can be traced for hundreds of miles from the mouth of the river. The economic importance of the study of the phenomena is obvious; the currents set up in an estuary can play a very large part in the movement of sediment, and the Clyde Navigation Trust has made a grant of $£ 8,000$ to intensify work on this aspect of the subject in the River Clyde. In a thermal power station it is important that the hot circulating water issuing is not taken back into the system. This latter problem has been the subject of investigation at the College for six years, and studies have been carried out on two large hydraulic scale-models of the circulating water systems of Methil and Cockenzie Generating Stations by the Civil Engineering Department on behalf of the South of Scotland Electricity Board. At present, Prof. Frazer is advising on the similar problem which may arise in connexion with the proposed 2,400-MW station at Longannet in Fife. This will involve the construction by the South of Scotland Electricity Board of a very large hydraulic scale model of the Forth Estuary.

\section{Television in the Medical School}

Av edited version of the verbatim transcript of the proceedings of the symposium Television in the Medical
School, arranged by the Association for the Study of Medical Education and the Scientific Film Association at the London Hospital Medical College, May 10-11, 1961, has now been issued (Pp. v +73. Edited by Charles Engel and John Ellis. London: Association for the Study of Medical Education, 1963). It includes the papers presented at the session on television in research, dealing with basic theory, radiology, microscopy, endoscopyophthalmoscopy, and behaviour study, and the subsequent discussions; those presented at the sessions on television in teaching, dealing with present-day applications and investigations of television in American medical and dental schools; the application of television in preclinical teaching; in teaching histology; in teaching psychiatry; television endoscopy in clinical teaching; and clinical applications in German universities, as well as the ensuing discussions. Finally, it includes the papers presented on installations and on minimum basic equipment for television, and the replies from a panel answering questions on equipment and staff given at the session on practical requirements and cost of television in the medical school.

\section{Soil Survey of Great Britain}

CHrew credit for the early steps in Britain on the examination of soils in the field, based on Russian, and later American, concepts of pedogenic processes and profile development, must be attributed to a small group of soil scientists including the late Prof. G. W. Robinson, Mr. Morley Davies, Sir William Ogg and Prof. T. Wallace. Meetings were held in various parts of the country to compare notes, discuss classification and initiate mapping. It was not until after the War, however, that the survey of soils was undertaken on a serious scale; it became one of the responsibilities of the Agricultural Research Council with the formation of the Soil Survey Research Board and an annual report of the work completed and in progress is issued; the present one provides the reader with an excellent account of the rapidly increased volume of information available on the soils of Great Britain (Report No. 15, 1962. Pp. vi +48. London: Agricultural Research Council. Obtainable from H.M.S.O., 1963. $5 s$. net). The scientific staff of the Soil Survey now numbers more than fifty; about two-thirds are employed in England and Wales with headquarters at Rothamsted, the remainder being in Scotland with headquarters at the Macaulay Institute. Frequent exchanges of views among surveyors are designed to maintain agreement in classification and nomenclature, and memoirs are published to explain and supplement the information on the maps. It will take many years to complete the soil map of the whole country; rapid reconnaissance is helpful, but detailed surveying is essential, and the effort spent has already been justified in the successful application of the results in agricultural and forestry problems. In addition to the regular mapping programme, assistance is frequently given in special surveys for such activities as Nature reserves, restoration of open-cast sites, archæological excavations, husbandry farms and field experimentation. An important contribution has been made in the production of a soil map of Europe, and officers are from time to time seconded to start or advance surveys of economic importance abroad.

\section{Bibliography of Seismology}

The Bibliography of Seismology continues its valuable work. It is compiled by J. H. Hodgson and F. E. Langill and published by the Dominion Observatory, Ottawa, for the Canadian Department of Mines and Technical Surveys. Nos. 5-10, Volume 22, which have been recently published, deal with work published during the years 1959,1960 and 1961 and together contain 2,954 items. Seismic prospecting provides 533 items, studies of crustal structure 140 entries, and studies of surface waves 166 notes. The 